\title{
RANCANGAN MASALAH MATEMATIKA UNTUK MENGIDENTIFIKASI BERPIKIR GEOMETRIS SISWA
}

\author{
Noor Fajriah \\ Universitas Lambung Mangkurat \\ n.fajriah@ulm.ac.id
}

\begin{abstract}
ABSTRAK
Berpikir geometris memiliki peran yang sangat penting untuk mengembangkan berpikir matematis siswa. Untuk mengetahui berpikir geometris siswa diperlukan suatu masalah yang dapat mengidentifikasi berpikir geometris. Masalah tersebut harus sesuai dengan tujuan yang akan diukur, memenuhi validitas dan reliabilitas sebagai alat penilaian. Tujuan penelitian ini adalah memperoleh rancangan masalah matematika untuk dapat mengidentifikasi berpikir geometris yang valid dan reliabel. Metode diskriptif digunakan dalam penelitian ini. Ada 6 orang sebagai validator dan 3 orang siswa SMP untuk uji coba. Hasilnya diperoleh prototipe masalah yang dirancang memperhatikan aspek materi sesuai dengan tingkat siswa SMP dan memunculkan aktivitas visualisasi, konstruksi dan penalaran. Aspek konstruksi dimana masalah tidak menimbulkan penafsiran ganda, jelas maksudnya dan menggunakan kata tanya/ perintah yang penyelesaiannya berupa uraian. Aspek bahasa dimana bahasanya komunikatif, mudah dipahami dan sesuai kaidah bahasa Indonesia yang baik dan benarserta memenuhi kriteria keterbacaan.
\end{abstract}

Kata kunci: berpikir geometris, masalah geometri, instrument penilaian, berpikir tingkat tinggi.

\begin{abstract}
Geometric thinking has a very important role in developing students' mathematical thinking. To find out geometric thinking students needed a problem that could identify geometric thinking. The problem must be in accordance with the objectives to be measured, to meet validity and reliability as a valuation tool. The purpose of this research was to obtain the design of geometry problems to be able to identify valid and reliable geometric thinking. The descriptive method was used in this research. There are 6 people as validators and 3 junior high school students for testing. The results obtained prototype problems designed to pay attention to aspects of the material in accordance with the level of junior high school students and bring visualization, construction and reasoning activities. The construction aspect in which the problem does not lead to multiple interpretations. is clear and uses a question word/ command whose completion is a description. Aspects of language where the language is communicative easily understood and in accordance with the rules of the Indonesian language is good and true and meets the criteria of legibility.
\end{abstract}

Keywords: geometrics thinking, geometrics problem, assessment instrument, high order thinking.

Format Sitasi: Fajriah, N. (2018). Rancangan Masalah Matematika untuk Mengidentifikasi Berpikir Geometris Siswa. KALAMATIKA Jurnal Pendidikan Matematika, 3(1), 39-50. 
Penyerahan Naskah: 3 September 2017 || Revisi: 12 Maret 2018 || Diterima: 13 Februari 2018

\section{PENDAHULUAN}

Berpikir geometris memiliki peran yang sangat penting untuk mengembangkan berpikir matematika karena dalam NCTM (2000) dituliskan bahwa geometri menawarkan aspek yang berbeda dari berpikir matematis. Berpikir geometris dapat melatih siswa berpikir logis untuk menalar, melatih siswa berpikir formal, melatih keterampilan siswa menyelesaikan masalah dan dapat mengembangkan berpikir spasial. Pernyataan tersebut diperkuat oleh Goos, dkk (2007) yang menyatakan bahwa jika berpikir geometris siswa meningkat maka dapat meningkat juga kemampuan imajinasi, memahami objek tanpa melihat bendanya danmemahami objek dinamis. Artinya dengan meningkatnya berpikir geometris siswa maka diharapkan meningkat juga hasil belajar geometri

Kenyataannya, hasil belajar geometri siswa belum optimal khususnya materi mengenai sudut dan kekongruenan segitiga. Penelitian Maulidah (2016) dan Putri (2017) menyimpulkan bahwa beberapa indikator dari pemahaman konsep siswa SMPN 5 Banjarmasin pada materi garis dan sudut berada pada kualifikasi kurang, indikator pemahaman konsep matematis siswa SMPN 13 Banjarmasin pada materi kekongruenan dan kesebangunan maksimal pada kualifikasi cukup. Berdasarkan hal tersebut perlu suatu masalah geometri mengenai kekongruenan dan sudut untuk mengetahui berpikir geometris siswa.

Masalah geometri yang diperlukan untuk mengetahui berpikir geometris siswa harus dapat mengidentifikasi berpikir geometris tersebut. Masalah tersebut harus sesuai dengan tujuan yang akan diukur, memenuhi validitas dan reliabilitas sebagai alat penilaian, Aspek masalah harus memenuhi kriteria materi, konstruksi dan bahasa yang digunakan siswa SMP.

Namun, masalah geometri yang disajikan pada buku teks tidak selalu dapat mengidentifikasi berpikir geometris siswa. Misalnya, ketika siswa dihadapkan pada masalah menentukan besar sudut suatu objek geometri maka objek geometrinya sudah diberikan. Siswa menjadi malas untuk mengkonstruksi objek tersebut tetapi akan membuat oret-oretan padagambar yang ada untuk memperoleh penyelesaian besar sudut yang ditanyakan kecuali jika guru mengharuskan siswa menggambar kembali objeknya. Berdasarkan hal tersebut maka perlu dirancang masalah yang dapat mengidentifikasi berpikir geometris siswa SMP sehingga diharapkan akan memunculkan aktivitas-aktivitas berpikir geometris. 
Aktivitas berpikir geometri menurut Duval (1998) ada tiga dan dapat dilakukan secara terpisah tetapi saling berhubungan erat. Aktivitas berpikir geometris tersebut adalah visualisasi, konstruksi dan penalaran.

Pertama adalah visualisasi dimana menurut Zimmermann \& Cunningham (1991) dan Hershkowitz (1990) adalah kemampuan, proses dan produk dari kreasi, interpretasi, penggunaan dan refleksi gambar, diagram di dalam pikiran, di atas kertas atau dengan teknologi untuk tujuan menggambarkan dan mengkomunikasikan informasi, memikirkan dan mengembangkan ide-ide yang sebelumnya tidak diketahui dan memajukan pemahaman.Duval (1998) menuliskan definisi visualisasi adalah representasi visual dari pernyataan geometri, eksplorasi heuristik dari situasi geometri yang kompleks. Ini termasuk transfer dari satu jenis representasi visual yang lain berkaitan dengan representasi ruang untuk menjelaskan komentar verbal, untuk investigasi situasi yang lebih kompleks. Jadi visualisasi adalah representasi visualuntuk menggambarkan dan menggunakan objek geometri untuk mengkomunikasikan informasi dari pernyataan yang diberikan di dalam pikiran atau kertas.

Aktivitas berpikir geometris kedua adalah konstruksi. Konstruksi menurut Duval (1998) merupakan suatu kegiatan untuk menggambarkan suatu konfigurasi sesuai dengan alat yang ada dan persyaratan geometris. Penggunaan alat seperti jangka dan penggaris sangat membantu siswa dalam konstruksi awal pembelajaran untuk memahami sifat-sifat dari objekobjek (Hoffer, 1981), “doing compass and straight edge construction early in the course helps students to understand properties of figures. Hal tersebut diperkuat oleh Napitipulu (Erduran \& Yesildere, 2010) menunjukkan bahwa pentingnya penggunaan jangka dan penggaris untuk membantu berpikir geometris siswa. Konstruksi menurut Ayama dan Chikwere (2016) diajarkan sebagai dasar dari geometri dan jika diajarkan dengan baik terkait konstruksi fisik sehingga gagasan tersebut menjadi lebih konkret dalam pikiran siswa. Jadi konstruksi adalah proses menggambarkan objek geometri pada kertas dengan bantuan alat (penggaris, jangka, busur derajat) yang memenuhi aturan geometris.

Selanjutnya, aktivitas berpikir geometris ketiga adalah penalaran. Duval (1998) menyatakan bahwapenalaran berhubungan dengan proses untuk bukti dan penjelasan. Penalaran (Torregrosa dan Quesada, 2008) dianggap sebagai proses menurunkan informasi baru dari informasi sebelumnya, mungkin berasal darimasalah itu sendiri atau dari pengetahuan sebelumnya. Sedangkan Santrock (2007) menuliskan penalaran adalah berpikir 
logis yang menggunakan penalaran induktif dan deduktif untuk menghasilkan kesimpulan.Sehingga penalaran adalah proses menjelaskan dalam memecahkan masalah untuk menghasilkan kesimpulan, baik secara induktif atau deduktif.

Ketiga aktivitas-aktivitas berpikir geometris tersebut diharapkan muncul pada saat siswa mengerjakan masalah yang diberikan. Masalah matematika dalam hal ini geometri yang diberikan harus memenuhi kriteria valid dan reliabel. Suatu alat penilai dikatakan valid (memenuhi validitas), jika alat tersebut dapat mengukur apa yang hendak diukur. Validitas dibedakan atas dua macam, yaitu validitas empiris dan validitas logis(Surapranata, 2004; Moleng, 2011; Sugiyono, 2014). Penelitian ini menggunakan validitas logis dengan memperhatikan segi materi, konstruk dan bahasa yang divalidasi ahli matematika (dosen dan guru).

Adapun untuk mengetahui reliabilitas masalah menggunakan reliabilitas internal. Reliabilitas berkaitan dengan sejauh mana masalah yang diberikan ajeg dari waktu ke waktu. Artinya reliabilitas berkaitan dengan dengan keajegan suatu masalah. Reliabilitas memiliki dua keajegan yaitu keajegan internal (tingkat sejauhmana masalah itu homogen baik dari segi kesukaran maupun bentuk soalnya) dan keajegan eksternal (tingkat sejauhmana skor dihasilkan tetap sama sepanjang kemampuan orang yang diukur belum berubah) (Surapranata, 2004; Moleng, 2011; Sugiyono, 2014). Keajegan internal, yaitu melihat apakah butir-butir masalah tersebut dapat berfungsi secara homogen untuk mengidentifikasi berpikir geometris siswa. Derajat reliabilitasnya tidak diukur secara numerik, karena bentuk masalahnya tidak dinilai atau diskor. Adapun yang diperhatikan adalah muncul atau tidaknya aktivitas berpikir geometris siswa dalam menyelesaikan masalah.

Penelitian ini bertujuan untuk memperoleh prototipe masalah kekongruenan yang valid dan reliabel. Selain itu juga dapat memunculkan aktivitas berpikir geometris visualisasi, konstruksi dan penalaran.

\section{METODE PENELITIAN}

Metode penelitian yang digunakan merupakan penelitian deskriptif dengan mendeskripsikan proses memperoleh prototipe masalah geometri untuk mengidentifikasi berpikir geometris siswa yang valid dan reliabel. Teknik pengumpulan data dengan angket, observasi dan wawancara. Angket digunakan untuk memperoleh validitas sedangkan observasi dan wawancara untuk memperoleh reliabelitas dari masalah. 
Penilaian berdasarkan aspek materi, konstruksi dan bahasa dilakukan oleh enam orang terdiri dari tiga orang dosen pendidikan matematika/matematika (Universitas Tadulako, UNS Solo dan ULM Bjm) dan tiga orang guru matematika yang ada di Kalimantan Selatan.

Prosedur dalam penelitian ini dilakukan sebagai berikut; masalahgeometri yang dirancang sebelumnya dikoreksi terlebih dahulu oleh dosen pendidikan matematika UNM dan Unesa dinamakan dengan rancangan masalah-1 (rm-1), selanjutnya rm-1 divalidasi oleh enam orang dari segi materi, konstruk dan bahasa yang menghasilkan rancangan masalah-2 (rm-2). Rm-2 tersebut diujicobakan kepada tiga orang siswa SMPN di Banjarmasin yang nantinya menghasilkan rancangan masalah-3 (rm-3).

Adapun kriteria-kriteria yang digunakan untuk melihat munculnya aktivitas berpikir geometris siswa yaitu: mengiluustrasikan objek geometri berdasarkan deskripsi verbal atau sebaliknya, menggambar objek geometri berdasarkan sifat-sifatnya dengan menggunakan alat yang sesuai, menjelaskan hubungan antar konsep geometri, menjelaskan alasan-alasan yang diperlukan untuk menarik kesimpulan (Fajriah, 2015).

\section{HASIL DAN PEMBAHASAN}

Materi menentukan besar salah satu sudut dalam suatu segitiga yang kongruen dipilihuntuk rancangan masalah. Selanjutnya rancangan tersebut dikoreksi oleh dosen pendidikan matematika UNM dan Unesa sehingga diperoleh masalah geometri yang dinamakan rancangan masalah 1 (rm-1) yaitu "Segitiga RST merupakan segitiga sama kaki dengan RS sama panjang dengan RTdengan dengan besar sudut puncaknya adalah $120^{\circ}$. Garis SP dan TQ merupakan perpanjangan garis TS ke P dan garis ST ke Q. Jika besar sudut TQR adalah $20^{\circ}$ maka tentukan besar sudut SRP”.

Rancangan masalah-1tersebut divalidasi oleh 6 orang terdiri dari 3 (tiga) orang dosen pendidikan matematika/matematika (Univ. Tadulako, UNS Solo, ULM Bjm) dan 3 (tiga) orang guru matematika tingkat SMP (SMPN 1 Martapura, SMPN 1 Marabahan dan SMPN 7 Banjarmasin). Validitas logissama dengan analisis analisis kualitatif terhadap soal, yaitu untuk menentukan berfungsi tidaknya suatu soal berdasarkan aspek yang telah ditentukan (Surapranata, 2004), dalam hal ini aspek materi, konstruksi dan bahasa. 
Tabel 1 menampilkan hasil validasi berdasarkan aspek materi, konstruksi dan bahasa.

Tabel 1. Pernyataan Validator Terhadap Rancangan Masalah 1 (rm-1)

\begin{tabular}{|c|c|c|c|}
\hline \multirow[t]{2}{*}{ No } & \multirow[t]{2}{*}{ Aspek yang dinilai } & \multicolumn{2}{|c|}{$\begin{array}{c}\text { Banyak } \\
\text { Validator }\end{array}$} \\
\hline & & Setuju & Tidak \\
\hline \multirow[t]{5}{*}{1} & Materi & & \\
\hline & $\begin{array}{l}\text { a. Penyelesaiannya memerlukan proses visualisasi (membuat sketsa/ } \\
\text { gambar/ simbol) }\end{array}$ & 6 & 0 \\
\hline & $\begin{array}{l}\text { b. Penyelesaiannya memerlukan proses konstruksi (menggunakan } \\
\text { penggaris, busur derajat dalam mengkonstruksi objek geometri) }\end{array}$ & 4 & 2 \\
\hline & $\begin{array}{l}\text { c. Penyelesaiannya memerlukan proses penalaran (menjelaskan } \\
\text { secara logis) }\end{array}$ & 6 & 0 \\
\hline & d. Materi soal sesuai dengan tingkat siswa yang digunakan & 6 & 0 \\
\hline \multirow[t]{4}{*}{2} & Konstruksi & & \\
\hline & a. Rumusan soal tidak menimbulkan penafsiran ganda & 6 & 0 \\
\hline & b. Informasi yang disampaikan jelas maknanya & 3 & 3 \\
\hline & $\begin{array}{l}\text { c. Rumusan pertanyaan menggunakan kata tanya/ perintah yang } \\
\text { menuntut jawaban uraian }\end{array}$ & 5 & 1 \\
\hline \multirow[t]{4}{*}{3} & Bahasa & & \\
\hline & $\begin{array}{l}\text { a. Rumusan soal menggunakan bahasa sederhana, komunikatif dan } \\
\text { mudah dipahami }\end{array}$ & 6 & 0 \\
\hline & $\begin{array}{l}\text { b. Kata/ kalimat yang digunakan dalam soal tidak bermakna ganda } \\
\text { (salah pengertian) }\end{array}$ & 5 & 1 \\
\hline & $\begin{array}{l}\text { c. Bahasa yang digunakan dan penulisannya sesuai dengan kaidah } \\
\text { bahasa Indonesia yang baik dan benar }\end{array}$ & 5 & 1 \\
\hline
\end{tabular}

Berdasarkan tabel 1 terlihat bahwa $100 \%$ validator menyatakan setuju penyelesaian masalah memerlukan proses visualisasi, penalaran dan sesuai dengan tingkat siswa yang digunakan; sedangkan $67 \%$ validator menyatakan setuju penyelesaian soal memerlukan proses konstruksi (penggaris, busur derajat). Jadi ada 2 orang saja tidak setuju bahwa rm-1 memunculkan aktivitas konstruksi. Sehingga secara keseluruhan sebesar $92 \%$ validator menyatakansetuju rm-1 valid dari aspek materidalam mengidentifikasi berpikir geometris siswa. Selanjutnya, ada $100 \%$ validator setuju bahwa rumusan pertanyaan menuntut jawaban uraian; ada $83 \%$ validator menyatakan bahwa soal tidak menampilkan penafsiran ganda; $50 \%$ validator setuju bahwa informasi yang digunakan jelas maknanya. Secara keseluruhan dapat disimpulkan bahwa $80 \%$ validator menyatakan bahwa rm-1 valid dari aspek konstruksi untuk mengidentifikasi berpikir geometris siswa. Akhirnya, bahwa 100\% validator setujubahasa yang digunakan sesuai dengan kaidah bahasa Indonesia; ada 83\% validator setuju bahwa soal mudah dipahami dan tidak mengakibatkan salah penafsiran. Jadi dapat disimpulkan bahwa 90\% validator menyatakan bahwa rm-1 valid dari aspek bahasa untuk mengidentifikasi berpikir geometris siswa. 
Secara keseluruhan bahwa rm-1 memenuhi validitas logis karena ada 80\% atau lebih validator setuju berdasarkan aspek materi, konstruksi dan bahasa. Selanjutnya rm-1 layak digunakan tanpa revisi oleh 50\% validator dan 50\% validator menyatakan bahwa rm-1 layak digunakan dengan revisi. Berikut ini saran-saran yang diberikan validator untuk revisi rm-1: besar sudut puncaknya adalah $120^{\circ}$. Sebaiknya diganti besar sudut $S R T$ adalah $120^{\circ}$ istilah tersebut tidak ada dalam kurikulum KTSP dan kurikulum 2013; konsistensi penulisan RST jangan RST; diketahui segitiga $R S T$ merupakan segitiga sama kaki dengan $\overline{R S}$ sama panjang dengan $\overline{R T}$ dengan dengan besar sudut puncaknya adalah $120^{\circ}$. Misalkan titik $P$ dan $Q$ terletak pada perpanjangan $\overline{S T}$ sedemikian hingga titik $S$ terletak diantara titik $P$ dan titik $T$, sedangkan titik $T$ terletak diantara titik $S$ dan titik $Q$. Tentukan besar sudut $S R P$ jika $\overline{S P}$ dan $\overline{T Q}$ sama panjang dan besar sudut $T Q R 20^{\circ}$; cek dengan cermat istilah atau notasi yang biasa digunakan guru dalam pembelajaran termasuk buku ajar yang biasa digunakan; hilangkan kata maka.

Rm-1 diperbaiki berdasarkan saran-saran enam orang validator yang menghasilkan rancangan masalah-2 (rm-2) sebagai berikut: "Segitiga RST merupakan segitiga sama kaki dimana sisi $R S$ sama panjang dengan sisi $R T$ dan besar sudut $S R T$ sama dengan $120^{\circ}$. Misalkan titik $T$ dan $Q$ terletak pada perpanjangan garis $S T$ sedemikian hingga titik $S$ terletak diantara titik $P$ dan titik $T$, sedangkan titik $T$ terletak diantara titik $S$ dan titik $Q$. Tentukan besar sudut $S R P$ jika $\overline{S P}$ dan $\overline{T Q}$ sama panjang dan besar sudut $T Q R$ adalah $20^{\circ}$.

Rancangan masalah-2 selanjutnya diujicobakan ke tiga orang siswa kelas IX SMPN 5 Banjarmasin dan SMPN 9 Banjarmasin. Menurut Creswell (2015) bahwa hal ini dilakukan untuk mengetahui apakah instrumen/rm-2nantinya mampu dipahami dan diselesaikan oleh subjek penelitian. Berdasarkan hasil analisis terhadap pekerjaan siswa tersebut apakah masalah tersebut memenuhi kriteria keterbacaan.

Subjek ujicoba (SU1) pada saat diberi rm-2 langsung membaca soal dalam hati beberapa saat, setelah itu mengambil busur derajat dan pensil. Awalnya subjek menggambar sisi alas dilanjutkan memutar-mutar busur derajat untuk menentukan besar sudut-besar sudut dalam suatu segitiga RST. Subjek ujicoba ini menggunakan busur derajat untuk mengukur panjang dan besar sudut. Subjek ujicoba (SU2) juga langsung membaca soal dalam hati dan mengambil penggaris lurus dan pensil untuk menggambar. Pada saat menggambarkan segitiga $R S T$ tanpa memperhatikan besar sudut yang diketahui hanya menggambarkan segitiga sama 
kaki RST berdasarkan sifat-sifat dua sisi sama panjang. Subjek ujicoba (SU3) setelah membaca rm-2 langsung mengambil penggaris lurus dan busur derajat tetapi ternyata yang digunakan hanya busur derajat. SU3 mula-mula menggambar sisi mendatar dan membentuk besar sudut $120^{\circ}$. Berdasarkan keterangan tersebut bahwa semua subjek melakukan dalam menggambar segitiga menggunakan penggaris lurus dan busur derajat. Hal ini sesuai denga kriteria aktivitas konstruksi yang ditulis Fajriah (2015) bahwa siswa menggambarkan objek geometri berdasarkan sifat-sifat dan menggunakan alat yang sesuai.

Alasan subjek-subjek menggunakan alat bantu untuk menggambar objek geometri karena akan lebih mudah memahami jika gambarnya lebih baik. Berikut ini contoh cuplikan wawancara:

SU1 : Setelah subjek membaca berulang-ulang dan mengambil pensil dan penggaris lurus.

$\mathrm{P} \quad$ : Penggaris tersebut digunakan untuk apa?

SU1 : Untuk menggambarkan maksud soalnya bu.

$\mathrm{P} \quad$ : Kenapa mesti digambarkan?

SU1 : Agar lebih memahami soalnya bu

$\mathrm{P} \quad$ : Kalau hanya membaca apa Asti sudah dapat memahami soal ini?

SU1 : Masih belum bu, belum bisa membayangkannya.

$\mathrm{P} \quad$ : Kan tidak perlu penggaris untuk dapat menggambarkan maksud soal tersebut.

SU1 : Nanti gambarnya benjot-benjot jadi susah memahaminya.

Berdasarkan cuplikan wawancara di atas juga terlihat bahwa siswa perlu menggambarkan apa yang dimaksud soal karena untuk lebih memahaminya karena tidak dapat dibayangkan saja. Artinya siswa perlu membuat ilustrasi segitiga yang dimaksud dalam rm-2 sehingga muncul salah satu kriteria aktivitas visualisasi ketika siswa menyelesaikanrm-2 (Fajriah, 2015).

Subjek ujicoba yaitu SU1 dan SU2 menjelaskan bahwa besar sudut SRT dan besar sudut RTSsama karena segitiga RST merupakan segitiga sama kaki, menjelaskan bahwa hubungan pasangan sudut $R T Q$ dan RTS, RSP dan RST saling berpelurus yang besarnya $180^{\circ}$, dapat menyimpulkan bahwa segitiga $R S T$ dan segitiga $R T Q$ saling kongruen dengan alasansisi $R S$ sama panjang dengan sisi $R T$, sudut $R S T$ sama besar dengan sudut $R T Q$, sisi $S T$ sama panjang dengan sisi $T Q$. Alasan yang dikemukakan subjek secara lisan dengan dengan bantuan gambar segitiga yang ada. Adapun SU3 memperlihatkan alasan dengan bantuan 
penggaris lurus dan busur derajat serta dikemukakan secara lisan. Ketiga subjek kebanyakan dalm memberikan alasan dengan berbicara dan menggunakan gambar tidak menuliskan kembali apa yang sudah dikemukakan. Jadi menurut (Alsina \& Nelsen, 2006) bahwa kecenderungan subjek uji coba menggunakan dua sumber komunikasi yaitu bahasa lisan dan bentuk dalam mengungkapkan penyelesain masalah yang diberikan.

Berdasarkan hal tersebut maka semua subjek dapat menyimpulkan bahwa segitiga $R S T$ dan segitiga $R T Q$ saling kongruen karena sisi $R S$ sama panjang dengan sisi $R T$, sudut $R S T$ sama besar dengan sudut $R T Q$, sisi $S T$ sama panjang dengan sisi $T Q$ walaupun dengan cara berbeda. Dua subjek dapat menyimpulkan dengan menyebutkan alasannya sedangkan subjek satunya menyimpulkan dengan menggunakan penggaris dan busur derajat. Sehingga berdasarkan Fajriah (2015) kriteria dari penalaran yang muncul adalah menjelaskan hubungan antar konsep geometri dan menjelaskan alasan-alasan yang diperlukan untuk menarik kesimpulan. Berikut ini contoh hasil pekerjaan salah satu subjek uji coba pada gambar 1 .

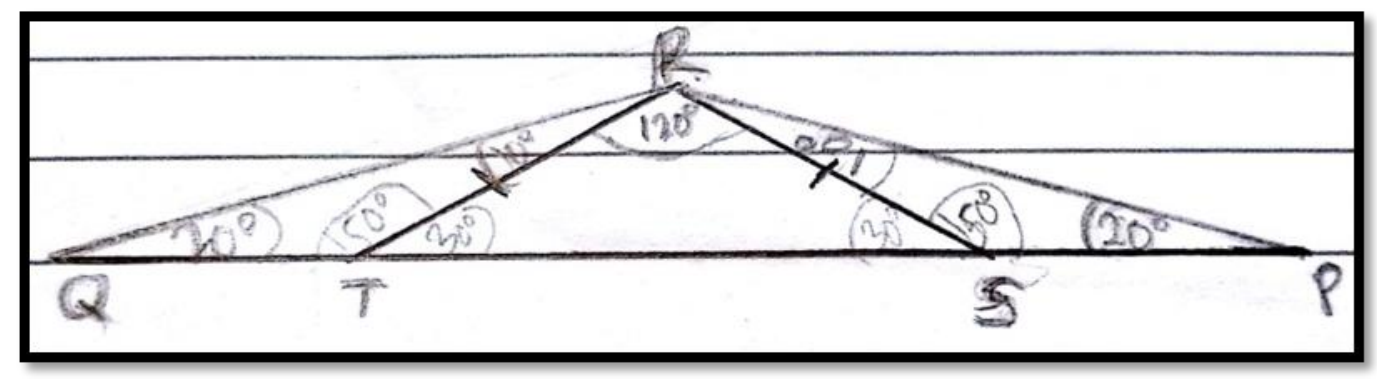

Gambar 1. Hasil Pekerjaan SU1

Subjek ujicoba SU1 dalam menyelesaikan masalah menggunakan strategi menggambar dan tidak menulis di luar gambar dan fokus dengan gambar tersebut. Gambarnya sesuai dengan persyaratan geometris yang disyaratkan misalkan panjang sisi yang sama benar sama ukurannya.

Ketiga subjek ujicoba mempunyai kecenderungan sama dalam menyelesaikan masalah yang diberikan dengan munculnya aktivitas berpikir geometris yang diharapkan. Sehingga rancangan masalah-2 telah memenuhi keajegan internal artinya masalah dapat berfungsi secara homogen untuk mengidentifikasi berpikir geometris siswa dengan kata lain rancangan masalah-2 memenuhi reliabilitas.

Rancangan masalah-2 sudah memenuhi syarat valid dan reliabilitas untuk mengidentifikasi berpikir geometris siswa SMP. Walaupun telah memenuhi syarat tersebut maka rm-2 masih direvisi sedikit dengan menurunkan satu kalimatmenjorok ke awal untuk 
menekankan bahwa bahwa pada kalimat terakhir tersebut merupakan hal yang ditanyakan sehingga masalah tersebut dinamakan rancangan masalah-3 (rm-3) sebagai berikut:

Segitiga RST merupakan segitiga sama kaki dimana sisi RS sama panjang dengan sisi RT dan besar sudut SRTsama dengan $120^{\circ}$. Misalkan titik T dan Q terletak pada perpanjangan garis ST sedemikian hingga titik $\mathrm{S}$ terletak diantara titik $\mathrm{P}$ dan titik $\mathrm{T}$, sedangkan titik $\mathrm{T}$

terletak diantara titik S dan titik Q. Tentukan besar sudut SRP jika $\overline{S P}$ dan $\overline{T Q}$ sama panjang dan besar sudut TQR adalah $20^{\circ}$. Akhirnya, rm-3 merupakan prototipe masalah kekonruenan segitiga yang dapat mengidentifikasi berpikir geometris siswa.

\section{KESIMPULAN}

Penelitian ini menghasilkan prototipe masalah geometri untuk mengidentifikasi berpikir geometris siswa SMP yang valid dan reliabel. Masalah yang dirancang memperhatikan aspek materi sesuai dengan tingkat siswa SMP dan memunculkan aktivitas visualisasi, konstruksi dan penalaran; aspek konstruksi dimana masalah tidak menimbulkan penafsiran ganda, jelas maksudnya dan menggunakan kata tanya/ perintah yang penyelesaiannya berupa uraian; dan aspek bahasa dimana bahasanya komunikatif, mudah dipahami dan sesuai kaidah bahasa Indonesia yang baik dan benar; serta memenuhi kriteria keterbacaan.

\section{REKOMENDASI}

Prototipe ini belum maksimal memunculkan semua aktivitas berpikir geometris semua siswa. Ada siswa hanya dengan aktivitas visualisasi dan aktivitas penalaran sudah mampu menyelesaikan sehingga perlu masalah matematika yang lebih memaksimalkan ketiga aktivitas tersebut.

\section{UCAPAN TERIMA KASIH}

Terima kasih kepada Tim Validator dan siswa yang bersedia meluangkan waktu membantu terlaksananya penelitian ini.

\section{REFERENSI}

Alsina, C. \& Nelsen, R. B. (2006). Math Made Visual Creating Images for Understanding Mathematics. New York: The Mathematical Association of America. 
Chikwere, P., \& Ayama, K. Teaching of Geometric Construction in Junior High School: An Intervention. Journal of Elementary Education, 26(1), 139-146.

Creswell, J. (2015). Riset Pendidikan: Perencanaan, Pelaksanaan dan Evaluasi Riset Kualitatif dan Kuantitatif. Yogyakarta: Pustaka Pelajar.

Duval, R. (1998). Geometry from a Cognitive Point of View. New ICMI Studies Series, 5, 3751.

Erduran, A. dan Yesildere, S. (2010). The Use of a Compass and Straightedge to Construct Geometric Structures. Elementary Education Online, 9(1).

Fajriah, N. (2015). Kriteria Berpikir Geometris Siswa SMP dalam Menyelesaikan Masalah Geometri. Math Didactic: Jurnal Pendidikan Matematika, 1(2), 103-108.

Goos, M., Stillman, G. \& Vale, C. (2007). Teaching Secondary School Mathematics (Research and Practice for the 21st Century). Australia: Allen \& Unwin.

Hershkowitz, R. (1990). Psychological aspects of learning geometry. Mathematics and cognition: A research synthesis by the International Group for the Psychology of Mathematics Education, 70-95.

Hoffer, A. (1981). Geometry More than Proof. Mathematics Teacher, 74(1), 11-18. (Online), (http://ilkogretim-online.org.tr), diakses 1 Agustus 2016.

Moleong. L.J. (2011). Metode Penelitian Kualitatif. Bandung: PT, Remaja Rosdakarya.

National Council of Teachers of Mathematics. (2000). Principles and Standards for School Mathematics. Reston, VA: NCTM.

Santrock, J.W. (2007). Psikologi Pendidikan. Alih bahasa Wibowo, T. Jakarta: Kencana Prenada Media Group.

Sugiyono. (2014). Metode Penelitian Kuantitatif Kualitatif dan $R \&$ D. Bandung: Alfabeta. 
Surapranata, S. (2004). Analisis, Validitas, Reliabilitas, dan Interpretasi Hasil Tes. Bandung: PT. Remaja Rosdakarya.

Torregrosa, G dan Quesada, H. (2008). The Coordination of Cognitive Processes In Solving Geometric Problems Requiring Formal Proof. In Proceedings of the Joint Meeting of the $32^{\text {nd }}$ Conference of the International Group for teh Psychology of Mathematics Education, and the XX North American (Vol. 4, pp. 321-328).

Zimmermann, W. \& Cunningham, S. (2011). Editors Introduction: What is Mathematical Visualization. In Visualization in Teaching and Learning Mathematics. Mathematical Association of America, 1-8. 